\title{
Stephen Teo, Director in Action: Johnnie To and the Hong Kong Action Film
}

Hong Kong, Hong Kong University Press, 2007, 294 pp.

\section{Kristof Van Den Troost}

\section{OpenEdition}

\section{Journals}

Electronic version

URL: http://journals.openedition.org/chinaperspectives/4790

DOI: $10.4000 /$ chinaperspectives. 4790

ISSN: 1996-4617

\section{Publisher}

Centre d'étude français sur la Chine contemporaine

Printed version

Date of publication: 1 April 2009

Number of pages: 110-112

ISSN: 2070-3449

\section{Electronic reference}

Kristof Van Den Troost, «Stephen Teo, Director in Action: Johnnie To and the Hong Kong Action Film », China Perspectives [Online], 2009/1 | 2009, Online since 01 April 2009, connection on 21 September 2020. URL : http://journals.openedition.org/chinaperspectives/4790 ; DOI : https://doi.org/10.4000/ chinaperspectives.4790

This text was automatically generated on 21 September 2020.

(c) All rights reserved 


\title{
Stephen Teo, Director in Action: Johnnie To and the Hong Kong Action Film
}

Hong Kong, Hong Kong University Press, 2007, 294 pp.

\author{
Kristof Van Den Troost
}

One of the most prominent directors in Hong Kong at the moment, Johnnie To Kei-fung, has over the past few years been receiving more attention at film festivals globally with films such as Breaking News (2004), Election I \& II (2005-2006), Exiled (2006), The Mad Detective (2007), and most recently, Sparrow (2008). Sometimes referred to as the post-1997 poet of Hong Kong, To has a career that actually goes back as far as the 1980s, and as one of the few directors to keep up a high output even after the local film industry started to decline, his CV now boasts close to 50 films. Writing a monograph on To is therefore no easy task, and there are few people as qualified to attempt it as Stephen Teo, who previously wrote an important history of Hong Kong cinema and studies of other Hong Kong directors such as Wong Kar-wai and King Hu. ${ }^{1}$

Teo's main theoretical concern - outlined in the first chapter - is how to accommodate genre theory with auteur theory to explain To's somewhat paradoxical position as an auteur working in the often disdained action genre. Teo proposes to consider To's "auteur function," a term derived from Michel Foucault's work that, in Teo's words, refers to "those functions specific to the auteur and his role in mediating, altering and transforming the codes of genre" (p. 14). To is therefore an "enunciator of pre-existent material," which makes him somewhat of a paradox: he seemingly submits to the system and questions it at the same time. This makes his films very complex, a complexity that also stems from their idiosyncrasy: To's films "all exert a certain quality that can only be identified as the personal touch of To" (p.16). Since Teo considers idiosyncrasy as essentially cultural, he also aims to pinpoint the cultural specificity of the mutual relation between To and the action genre. This cultural specificity "determines the way the films respond to the specific urban culture of Hong Kong, and how the characters' behavior drive the pacing and the rhythm of the 
narratives" (p. 16). While To's films indeed raise questions about genre and auteurism, the director is perhaps not so unique as Teo makes him appear: one can think of many filmmakers who once occupied a similar position (for instance, Alfred Hitchcock, John Ford, and in a Hong Kong context, John Woo). What makes Johnnie To more problematic, however, is what Teo calls his "unevenness": the system influences the efficacy of To's auteur function, making him an "uneven auteur" whose "essential characteristics are attenuated across genres" (p. 19). In this manner, Teo explains how To excels in the action film while simultaneously producing rather unremarkable romantic comedies and other genre films.

3 In the next four chapters, different phases of To's career are closely investigated. Chapter Two takes as its subject the films of the period before 1996, when To established his own company, Milkyway Image. Tracing various elements that recur in the director's films in the action genre, the chapter shows how To gradually develops his art. The first true masterpieces, however, appear only during the Milkyway period discussed in the third chapter. Ironically, the director credits of most of these early Milkyway works went to To's protégés (particularly Patrick Yau), although it is now generally accepted that To directed most of Yau's films. The themes of fatalism, impermanence, and death are prominent in these films, resonating with the uncertainty and despair surrounding the handover of sovereignty in 1997.

4 From 1998 on, To started directing films under his own name again, producing what Teo in Chapter Four follows To in calling "exercises," including films such as The Mission (1999), Running out of Time (1999), PTU (2003), and Breaking News (2004) - all films that helped establish To's name internationally. Chapter Five discusses films made in the same period as those of the previous chapter, but not as accomplished or easily classified. Five films are discussed: Needing You (2000), Help! (2000), Fulltime Killer (2001), Running on Karma (2003), and Throw Down (2004). Teo puts them together and calls them "neo-exercises" with the argument that they all illustrate To's "unevenness" as an auteur. He gives this "unevenness" various meanings depending on the film, so that while in Needing You it refers to a funny sight gag in a not so funny film, in Fulltime Killer it refers to the inconsistency of language, and in Throw Down to the quirky narrative. With such an open definition of "unevenness," the term seems to lose its meaning and makes its application appear like an excuse to put these very different films together in one chapter. Teo admits as much when he states at the end of the chapter that his theme of "unevenness' is a "structural conceit" (p. 175). It shows how difficult it is to write about a director with such a large, varied, and indeed, qualitatively uneven body of work, and raises the question of whether another structure for the book would have been better: chapters focusing on the varied and developing treatment of certain themes in To's work seems like a good alternative in this regard, although it would inevitably lead to a less chronological and straightforward account than the one offered by Teo.

Illustrating the risks involved in writing about a very productive and innovative director, Teo had to add a postscript to his book to keep abreast of To's prolific output. This postscript deals with Election I and II, as well as Exiled, and focuses on To's treatment of violence in these films. Teo puts these recent films in the category of the "neoexercises" he used to describe the "uneven" films in Chapter Five. This classification seems inappropriate, however, because unlike most of the films in the fifth chapter, these more recent films received considerable critical and popular 
acclaim. It begs the question of whether To's career has entered a new phase, and whether the categories of "exercises" and "neo-exercises" are useful at all in thinking about To's films of the last ten years. Finally, in the epilogue, Teo summarises some of the points he made about Johnnie To and his films throughout the book, focusing in particular on how To's style of filmmaking defies and transmutes spectator expectations of the genre. This is most clearly illustrated by his handling of the convention of the happy ending, which in To's films often isn't all that happy.

Unfortunately for Teo, since his book came out in 2007, To has directed and/or produced seven new films, amongst which two (The Mad Detective and Sparrow) are of obvious critical importance to an assessment of his career, since they show To taking his experiments in a somewhat different direction. The Mad Detective harks back to previous masterpieces (especially PTU and The Longest Nite), but adds supernatural/ magical elements to the mix (the detective's ability to see people's multiple personalities, for instance). The supernatural returns in Linger (2008), where the main character experiences various encounters with her deceased lover's ghost, and also in Sparrow there seems little concern with realism. This last film is perhaps To's most personal and light-hearted film to date (with the possible exception of Throw Down), and is a wonderful homage to (old) Hong Kong. In a number of ways the film is also a further attempt to combine the two genres To is famous for: the action film and the romantic comedy (something he started to work towards in the Andy Lau-Sammi Cheng vehicle Yesterday Once More, 2004). These movies reveal To's further development as an absolute master of the image, his recycling of old themes and ideas, and his experiments towards a new kind of cinema - one with relatively little concern for conventional plot development, realism, and characterisation, but brilliant in its creation of atmosphere, its combination of music and the visual, and its (generic) innovativeness.

7 Despite these more recent developments in To's oeuvre, one has to admire how accurately Teo identifies recurring themes and motifs in the director's films, in this way proving the book's insightfulness and continuing relevance. Director in Action is thus a must-read for anyone interested in Hong Kong cinema and one of its most prominent directors, Johnnie To.

\section{NOTES}

1. (1) See: Hong Kong Cinema: The Extra Dimensions, London, BFI Pub., 1997; Wong KarWai, London, BFI Pub., 2005; King Hu's A Touch of Zen, Hong Kong, Hong Kong

University Press, 2007. 


\section{AUTHOR}

\section{KRISTOF VAN DEN TROOST}

Ph.D candidate at the Chinese University of Hong Kong. 